\title{
MENGANGKAT KASUS POLITIK AKTUAL DALAM PEMBELAJARAN PENDIDIKAN KEWARGANEGARAAN
}

Oleh: Sunarso

(FISE - UNY)

\begin{abstract}
Abstrak
Materi untuk pembelajaran Pendidikan Kewarganegaraan (PKN) erat sekali hubungannya dengan kajian dalam bidang politik. Sedangkan kajian dalam bidang ilmu politik sangat dipengaruhi oleh perkembangan realitas politik di suatu negara baik yang masuk dalam wilayah supra struktur politik maupun yang masuk dalam infra struktur politik.

Pembelajaran dan kajian PKN yang mengabaikan perkembangan dan dinamika politik akan kehilangan kontektulitas, kehilangan daya tarik, serta kurang bermanfaat bagi peserta didik. Oleh karena itu, pemahaman dan penguasaan pengampu Pendidikan Kewarganegaraan pada berbagai persoalan politik beserta dinamika dan perkembangannya merupakan suatu keniscayaan.
\end{abstract}

\section{Pendahuluan}

"Kebesaran suatu negara tidak dinilai dari tingginya pendapatan nasional maupun benteng-bentengnya yang kuat dan hebat, ataupun dari bangunan-bangunan yang indah dan megah, melainkan hanya dari orang-orangnya yang terdidik dan terlatih baik, yang beradab dan berakhlak. Pada orang-orang inilah negara mendapatkan kekuatan yang sebenarnya" (Martin Luther King).

"Negara yang baik bisa dipelihara jika dikelola oleh pemerintahan yang baik, dan pemerintah menjadi baik jika berada di tangan orang-orang terbaik" (Lee Hsien liong).

Pendidikan di Indonesia diharapkan dapat mempersiapkan peserta didik menjadi warga negara yang memiliki komitmen kuat dan konsisten untuk mempertahankan Negara Kesatuan Republik Indonesia. Hakikat negara kesatuan Republik Indonesia adalah negara kebangsaan modern. Negara kebangsaan modern adalah negara yang pembentukannya didasarkan pada semangat kebangsaan - atau nasionalisme - yaitu pada tekad suatu masyarakat untuk membangun 
masa depan bersama di bawah satu negara yang sama walaupun warga masyarakat tersebut berbeda-beda agama, ras, etnik, atau golongannya.

Indonesia di masa depan diharapkan tidak akan mengulang lagi sistem pemerintahan otoriter yang membungkam hak-hak warga negara untuk menjalankan prinsip demokrasi dalam kehidupan masyarakat, bangsa, dan negara. Kehidupan yang demokratis di dalam kehidupan sehari-hari di lingkungan keluarga, sekolah, masyarakat, pemerintahan, dan organisasi-organisasi non-pemerintahan perlu dikenal, dimulai, diinternalisasi, dan diterapkan demi kejayaan bangsa dan negara Indonesia.

Demokrasi dalam suatu negara hanya akan tumbuh subur apabila dijaga oleh warga negara yang demokratis. Warga negara yang demokratis bukan hanya dapat menikmati hak kebebasan individu, tetapi juga harus memikul tanggung jawab secara bersama-sama dengan orang lain untuk membentuk masa depan yang cerah. Sesungguhnya, kehidupan yang demokratis adalah cita-cita yang dicerminkan dan diamanatkan oleh para pendiri bangsa dan negara ketika mereka pertama kali membahas dan merumuskan Pancasila dan UUD 1945.

Berkenaan dengan hal-hal yang diuraikan di atas, pendidikan memiliki peranan dan tanggung jawab yang sangat penting dalam mempersiapkan warga negara yang memiliki komitmen kuat dan konsisten untuk mempertahankan Negara Kesatuan Republik Indonesia. Upaya yang dapat dilakukan adalah menyelenggarakan program pendidikan yang memberikan berbagai kemampuan sebagai seorang warga negara melalui mata kuliah atau mata pelajaran Pendidikan Kewarganegaraan (Citizenship).

Pendidikan Kewarganegaraan (Citizenship) merupakan mata kuliah yang memfokuskan pada pembentukan diri yang beragam dari segi agama, sosio-kultural, bahasa, usia, dan suku bangsa untuk menjadi warga negara Indonesia yang cerdas, terampil, dan berkarakter yang dilandasi oleh Pancasila dan UUD 1945.

\section{Fungsi dan Tujuan Pendidikan Kewarganegaraan}

Fungsi Pendidikan Kewarganegaraan adalah sebagai wahana untuk membentuk warga negara yang cerdas, terampil, dan berkarakter yang setia kepada bangsa dan negara Indonesia dengan merefleksikan dirinya dalam kebiasaan berfikir dan bertindak sesuai dengan amanat Pancasila dan UUD 1945. 
Sedangkan tujuan Pendidikan Kewarganegaraan memberikan kompetensi sebagai berikut:

1. Berfikir secara kritis, rasional dan kreatif dalam menanggapi isu kewarganegaraan.

2. Berpartisipasi secara aktif dan bertanggung jawab, dan bertindak secara cerdas dalam kegiatan bermasyarakat, berbangsa dan bernegara.

3. Berkembang secara positif dan demokratis untuk membentuk diri berdasarkan pada karakter masyarakat Indonesia agar dapat hidup bersama dengan bangsa-bangsa lain.

4. Berinteraksi dengan bangsa lain dalam percaturan dunia secara langsung atau tidak langsung dengan memanfaatkan teknologi informasi dan komunikasi (Pusat Kurikulum, 2003: 3).

\section{Substansi Materi Pendidikan Kewarganegaraan}

Berdasar hasil studi di berbagai negara, Print (1999: 12) berpendapat bahwa isi Pendidikan Kewarganegaraan yang prinsip adalah:

1. Hak dan tanggung jawab warga negara.

2. Pemerintahan dan lembaga-lembaga.

3. Sejarah dan konstitusi.

4. Identitas nasional.

5. Sistem hukum dan rule of law.

6. Hak asasi manusia, hak-hak politik, ekonomi dan sosial.

7. Proses dan prinsip-prinsip demokrasi.

8. Partisipasi aktif warga negara dalam wacana kewarganegaraan.

9. Wawasan internasional.

10. Nilai-nilai dari kewarganegaraan yang demokratis.

Waterwoth (1998: 3) mengemukakan tentang butir-butir concept of citizenship dan warga negara yang baik, yaitu:

1. Menghargai warisan budaya masyarakatnya.

2. Menggunakan hak pilih.

3. Menghormati hukum dan norma-norma masyarakat.

4. Memahami berbagai proses politik dan ekonomi.

5. Menggunakan hak berbicara.

6. Memberikan sumbangan bagi kebaikan keluarga dan masyarakat.

7. Peduli terhadap lingkungan lokalnya. 
Sedangkan Abdul Azis Wahab (2000: 5) mengemukakan sepuluh pilar demokrasi Indonesia yang harus menjadi prinsip utama pengembangan Pendidikan Kewarganegaraan, yaitu:

1. Konstitusionalisme.

2. Keimanan dan ketaqwaan terhadap Tuhan Yang Maha Kuasa.

3. Kewarganegaraan cerdas.

4. Kedaulatan rakyat.

5. Kekuasaan hukum.

6. Hak asasi manusia.

7. Pembagian kekuasaan.

8. Sistem peradilan yang bebas.

9. Pemerintahan daerah.

10. Kesejahteraan sosial dan keadilan sosial.

Berdasarkan uraian di atas diperoleh gambaran tentang keragaman luasnya cakupan materi dan penataan Pendidikan Kewarganegaraan dalam kurikulum. Hal ini bukanlah sesuatu yang harus dianggap aneh, sebab kurikulum pada dasarnya adalah suatu pilihan. Dilihat dari sudut keilmuan, standar materi mata pelajaan ini tidak sedemikian ketat, cukup fleksibel, bahkan mudah berubah. Indonesia sendiri mempunyai pengalaman mengenai sering diubahnya isi materi mata kuliah ini, seiring dengan pergantian rezim sebagaimana yang telah dikemukakan sebelumnya. Dari sekian banyak mata kuliah/mata pelajaran, tidak ada yang perubahan materinya sedinamis mata kuliah Pendidikan Kewarganegaraan. (Muchson, 2003).

Pusat kurikulum Depdiknas lewat konsep KBK Kewarganegaraan di SD dan MI, SMP dan MTs, serta SMA dan MA tahun 2003, mengajukan civic knowledge berupa aspek berbangsa dan bernegara yang terdiri dari sub aspek:

1. Persatuan bangsa;

2. Norma, hukum dan peraturan;

3. Hak asasi manusia;

4. Kebutuhan hidup warga negara;

5. Kekuasaan dan politik;

6. Masyarakat demokratis;

7. Pancasila dan konstitusi negara,

8. Globalisasi (Cholisin, 2004:18).

Aspek-aspek dari pengetahuan kewarganegaraan di atas pada dasarnya merupakan pengetahuan yang berkaitan dengan peran warga negara dalam kehidupan berbangsa dan bernegara yang demokratis. Dari 8 aspek tersebut yang terkait dengan pilar politik adalah aspek 
No. 5, Kekuasaan dan Politik, serta aspek No. 6, Masyarakat Demokratis, yang bila diuraikan unsur-unsurnya adalah sebagai berikut:

\begin{tabular}{|l|l|}
\hline Kekuasan dan Politik & a. Pemerintahan daerah \\
& b. Pemerintahan pusat \\
& c. Kedaulatan rakyat dan sistem politik \\
& d. Otonomi Daerah \\
& e. Budaya politik \\
& f. Sistem politik \\
& g. Sistem pemerintahan \\
\hline \hline Masyarakat & a.Tanggung jawab dan toleransi \\
demokratis & b. Keputusan bersama \\
& c. Hubungan yang demokratis \\
& d. Hakikat demokrasi \\
& e. Budaya demokrasi \\
& f. Peranan pers dalam masyarakat \\
\hline
\end{tabular}

\section{Beberapa Hal yang Perlu Dipertimbangkan dalam Memilih Kasus}

Kasus Politik yang dijadikan contoh dalam pembelajaran PKN bidang politik hendaknya memperhatikan hal-hal sebagai berikut:

1. Relevan dengan kompetensi yang diajarkan;

2. Aktual dan menarik perhatian publik;

3. Mampu memotivasi peserta didik untuk menggali informasi yang lebih dalam;

4. Rujukan yang digunakan untuk mengurai kasus harus aktual dan dan bisa dipertanggungjawabkan;

5. Penanganan kasus mampu menawarkan alternatif solusi yang mencerahkan, bagi peserta didik, bila mungkin juga bagi masyarakat;

6. Alternatif solusi diharapkan bersifat obyektif, rasional, dan bermanfaat;

7. Analisis kasus dikaitkan dengan filosofi Pancasila.

\section{Beberapa Contoh Kasus Bidang Politik}

\section{Konflik Internal Partai}

(Sumber: Litbang Kompas, 2002)

Konflik internl partai bukan hal yang baru dalam sejarah partai politik di Indonesia. Sudah sejak zaman pemerintahan Soekarno. 
Begitu rezim Orde Baru Runtuh, penyakit ini menular pada partaipartai yang baru lahir. Partai-partai besar semacam Golkar, PDI Perjuangan, dan PPP yang sudah malang melintang pada rezim itu masih saja belum mampu membiakkan sistem kekebalan tubuh terhadap penyakit ini. Partai-partai yang pada kelahirannya menimbulkan harapan baru, seperti PKB dan PAN, tak terhindar dari perseteruan internal. PBB dan partai-partai kecil lainnya juga sama saja. Yang paling menonjol adalah rebutan kedudukan atau kekuasaan di dalam partai. Tidak mengherankan bila konflik-konflik itu berujung pada kepengurusan kembar. Penyebabnya antara lain konsolidasi partai yang rapuh dan perbedaan kepentingan antara kader yang amat bergam.

\section{a. Konflik Internal Partai Golkar:}

1) Setelah pemilu 1997, terjadi perbedaan pendapat di antara dua kubu mengenai calon wakil presiden yang akan mendampingi Presiden Soeharto (14 Januari 1998). Ketua umum DPP Golkar Harmokodan BJ. Habibie, akan tetapi Harmoko mengundurkan diri dan Habibie yang menjadi wakil presiden.

2) Setelah Soeharto runtuh, konflik dalam tubuh partai semakin menguat. Persaingan anatara kubu Akbar Tanjung dengan kubu Edi Sudradjat dalam pemilihan ketua umum. Terpilihnya Akbar Tanjung membuat Edi Sudradjat mendirikan partai baru, Partai Keadilan dan Persatuan (15 Januari 1999).

3) Setelah beberapa kadernya masuk dalam jajaran pemerintahan Presiden Abdurrahman Wahid konflik internal partai masih sering terjadi. Antara kelompok yang tetap mendukung pemerintah Presiden Wahid dan kelompok yng menginginkan presiden mundur.

\section{b. Konflik Internal Partai PDI Perjuangan}

1) Pada akhir pemerintahan Soeharto, PDI terpecah menjadi dua kubu, Kubu Megawati dan kubu Soerjadi.

2) Di kota Medan massa PDI kubu Megawati (9 Juli 1998) mengambil alih kantor DPD PDI dari tangan PDI kubu Soerjadi. Menjelang Pemilu 1999. Kubu Megawati akhirnya mendeklarasikan nama baru PDI, yaitu PDI Perjuangan, yang akhirnya meraih suara terbanyak dalam pemilu.

3) 27 Maret 2000 muncul dua kelompok yang bersaing untuk memperebutkan posisi ketua umum PDI Perjuangan. Kelompok pertama menginginkan Megawati tetap memimpin partai, 
sedangkan kelompok kedua menginginkan Megawati lebih berkonsentrasi sebagai wakil presiden saja.

\section{c. Konflik Internal Partai PPP}

1) Menjelang pemilu 1997 rebutan kursi calon legislatif yang menjurus ke saling pecat di berbagai daerah, terjadi di Riau dan Sulawesi Selatan.

2) Semasa Habibie menjabat presiden banyak kader PPP yang keluar dan mendirikan partai baru, seperti PKB, PAN, Partai Keadilan, dan PBB.

3) Januari 2002 PPP pecah, Zainuddin MZ mendirikan Partai Persatuan Pembangunan Reformasi.

\section{d. Konflik Internal PKB}

1) Perseteruan antara Ketua Umum PKB Matori Abdul Djalil dan Alwi Shihab mengenai sikap partai berhubungan dengan akan dilengserkannya Presiden Wahid, yang juga ketua Dewan Syuro PKB. Akhirnya Matori tetap hadir dalam sidang istimewa MPR, padahal DPP sudah memutuskan untuk memboikot sidang itu. Akhirnya Matori dipecat dari ketua umum PKB.

2) Setelah Matori menjadi menteri, ia menyatakan diri sebagai ketua umum PKB yang sah (30 juli 2001).

3) Dalam muktamar luar biasa di Yogyakarta digelar 20 Januari 2002, akhirnya Alwi Shihab terpilih sebagai ketua umum PKB.

\section{e. Konflik Internal PAN}

Sebanyak 16 anggota Pan, antara lain Faisal Basri dan Bara Hasibuan, pada tanggal 21 Januari 2001 mundur dari partai karena merasa PAN tidak lagi sesuai dengan platform partai.

\section{f. Konflik Internal Partai Keadilan}

1) Presiden PK Nurmahmudi Ismail 3 Mei 1999 mundur dari PK karena hendak bekerja sepenuhnya sebagai pegawai negeri. Namun Nurmahmudi menolak bila dikatakan mundur karena hendak bergabung dengan PKB.

2) Massa PK 10 November 2000 berunjuk rasa meminta pengembalian dana sebesar Rp 2,8 milyar yang disimpan di Baitul Mal wat Tamwil. 


\section{DPR dan Fungsi Legislasi}

(Sumber: Indonesia dalam Krisis, Sisilia Srisuwastuti)

Kebiasaan titip tanda tangan pertanda hadir bukan monopoli mahasiswa yang sedang malas, tetapi juga anggota DPR. Lihatlah daftar hadir rapat paripurna pengesahan UU Ketenaganukliran pada 26 Februari 1997. Tak kurang dari 317 baris nama terbubuh tanda tangan, namun yang hadir secara fisik dalam rapat itu taklebih dari 75 anggota. Begitu pula saat UU Tindak Pidana Pencucian Uang disahkan tanggal 25 maret 2002, sebanyak 260 dari 309 anggota menyatakan kehadirannya hanya dengan tinta. Tindak kriminal atau perbuatan amoral telah berlangsung di gedung parlemen: pemalsuan tanda tangan atau berbohong.

Perilaku buruk ini sempat menyerap perhatian publik. Tak mengherankan bila DPR dicap tak pernah bisa optimal menyalurkan aspirasi rakyat. Jajak pendapat Kompas 10 juni 2002 mengungkapkan tingkat ketidakpuasan masyarakat terhadap kinerja DPR terus menguat. Bila pada Agustus 2000 sekitar 52,5 persen dari 1569 responden menyatakan tidak puas, maka pada Mei 2002 tingkat ketidakpuasan naik menjadi 81,0 persen dengan 830 responden.

Begitu kekuasaan Soeharto berakhir, aktualisasi fungsi DPR bergeser. Bila pada masa Orde Baru lembaga ini tak lebih dari tukang stempel pemerintah, kini DPR cenderung berkonsentrasi pada fungsinya sebagai pengawas kebijakan pemerintah. Hal ini dipertontonkan kepada rakyat, melalui siaran televisi dalam masa pemerintahan Abdurrahman Wahid. Rapat paripurna pengambilan keputusan untuk membentuk Pansus Bulog I pada 5 september 2000, misalnya, dijejali anggota yang antusias maupun yang menentang.

Konsentrasi pada fungsi pengawasan ini mengendorkan fungsi lainnya. Salah satu adalah fungsi legislasi, fungsi membuat UU. Fakta ini barangkali bisa menjelaskan. Sejak tahun 1966 hingga 2001 terdapat 493 undang-undang yang dihasilkan pemerintah dan DPR. Rata-rata 13 sampai 14 undang-undang per tahun. Itu masa lalu. Tahun 2001 ditargetkan penetapan 30 undang-undang dan menyusun 40 RUU. Nyatanya hanya 22 UU yang ditetapkan sepanjang tahun 2001. Dalam hal penyusunan RUU, hanya 9 RUU dari 58 buah prioritas yang akhirnya menjadi UU.

Indikasi fungsi legislasi yang belum optimal ini diperlihatkan pula oleh minimnya RUU inisiatif DPR. Dari 493 UU yang dihasilkan selama 35 tahun, hanya 8,1 persen yang merupakan inisiatif DPR. Selang waktu 1966-1972 merupakan masa yang menghasilkan usulan 
terbanyak, tapi 20 RUU inisiatif akhirnya kandas di tengah jalan. Hanya tujuh usulan yang berhasil disahkan menjadi UU.

Fungsi legislasi untuk menciptakan UU yang benar-benar dibutukan rakyat banyak tampaknya jauh dari optimal. DPR hasil lima kali pemilu, sejak tahun 1971 sampai 1992, adalah DPR vakum mutlak dalam urusan ini. Tak satu pun usulan inisiatif dalam 25 tahun itu. Sepanjang itu pula hak inisiatif hanya dikenal dalam buku-buku pelajaran sekolah. Ia baru muncul lagi dalam tahun 1997-1999. Lima dari delapan RUU inisiatif disahkan menjadi UU. DPR hasil pemilu demokratis sejak tahun 1955, hingga tahun 2001 telah menghasilkan lima RUU inisiatif. Namun rupanya kepentingan politik sangat mendominasi usulan inisiatif DPR itu. Tujuh dari sepuluh RUU usul inisiatif DPR mengatur politik dan keamanan. Dua tentang ekonomi, keuangan, dan industri. Hanya satu RUU yang menyangkut kesejahteraan rakyat.

Dari substansinya, tak sedikit undang-undang yang setelah disahkan justru menimbulkan kontroversi hingga pelaksanaannya harus ditunda. UU Nomor 14 Tahun1992 tentang Lalulintas dan Angkutan Jalan dan UU Nomor 56 Tahun 1999 tentang Rakyat Terlatih merupakan undang-undang yang menimbulkan polemik.

Kewenangan eksekutif mengusulkan RUU bisa jadi alasan mengapa RUU banyak datang dari pemerintah. Namun, amandemen UUD 1945 yang memberi porsi besar kepada dewan ternyata juga bukan jaminan membaiknya kinerja DPR dalam fungsi legislasi.

\section{DPR di Mata Publik, Masih Mengedepankan Kepentingan Partai dan Pribadi} (Sumber: Indonesia Dalam Krisis, Nurul Fatchiati)

Sungguh besar harapan rakyat terhadap DPR hasil Pemilihan Umum 1999. Di samping terpilih melalui pemilu yang dianggap paling demokratis sejak rezim Orde Baru berkuasa, anggota DPR kali ini mempunyai latar belakang kualitas yang dipandang lebih baik dari pada yang pernah ada sebelumnya. Dari segi pendidikan formal $83 \%$ adalah lulusan perguruan tinggi. Proporsi mereka yang berusia muda berumur di bawah 50 tahun, jga cukup besar mencapai $43 \%$ dari seluruh anggota.

Dengan kondisi demikian, wajar jika rakyat menggantungkan harapan besar agar DPR lebih banyak berperan dan berpihak kepada rakyat. Paling tidak, dengan fungsinya membuat undang-undang, mengawasi pelaksanaan undang-undang dan kebijakan pemerintah, serta menampung dan menindaklanjuti berbagai aspirasi dan 
pengaduan masyarakat, seyogyanya lembaga ini lebih mengutamakan kepentingan rakyat.

Menjelang tiga tahun masa jabatannya pada 1 oktober 2002, DPR secara akumulatif telah menetapkan sekurangnya $60 \mathrm{UU}$, tetapi jumlah tersebut masih jauh dari target. Mengacu pada Repeta 2001, misalnya, DPR hanya mampu memproduksi $22 \mathrm{UU}$, atau hanya $25 \%$ dari target sebanyak 70 UU di tahun itu. DPR juga masih miskin inisiatif dalam menjalankan fungsi legislatif, sebab hanya sedikit RUU yang lahir dari tangan lembaga ini. Padahal mengacu pada Perubahan Pertama UUD 1945 Pasal 20, kekuasaan membuat UU sudah bergeser dari pemerintah kepada DPR.

Tugas yang termasuk cukup berhasil DPR periode ini tampaknya adalah mengawasi jalannya roda pemerintahan. Pada awal tugasnya, mereka aktif menyoroti sepak terjang pemerintah dan taksegan menggunakan hak-haknya, terutama hak interpelasi, hak angket, dan hak pernyataan pendapat. Sepanjang pemerintahan Presiden Abdurrahman Wahid, DPR menggunakan hak interpelasi sebanyak dua kali: terhadap pembubaran Departemen Penerangan dan Departemen Sosial, serta pencopotan Jusuf Kalla dan Laksamana Sukardi dari jabatan menteri.

Hak lain yang pernah difungsikan adalah hak angket dalam kasus pengucuran dana Yanatera Bulog sebesar Rp 35 milyar dan dana pemberian Sultan Brunei Darussalam Hassanal Bolkiah sebesar 2 juta dollar AS. DPR juga menggunakan hak pernyataan pendapat sebanyak dua kali: atas jawaban Presiden Abdurrahman Wahid terhadap pemecatan Jusuf Kalla dan Laksamana Sukardi yang dinilai tidak memuaskan, dan ketika Presiden Abdurrahman Wahid dianggap telah melanggar Pasal 35 UUD 1945, empat Ketetapan MPR, dan dua UU.

DPR terhitung rajin membentuk berbagai panitia khusus di luar panitia kerja. Umumnya panitia yang dibentuk berhubungan dengan pengungkapan kasus tertentu, seperti pengucuran BLBI dan penyalura dana Bulog, ataupun yang berkaitan dengan rekrutmen pada lembaga negara tertentu, seperti rekrutmen hakim agung dan anggota KPKPN. Namun, serangkaian prestasi yang telah dicapai DPR belum mampu membuat kinerja lembaga ini mendapat pujian berarti, setidaknya di mata sebagian publik. Hasil jajak pendapat berseri menunjukkan semakin lama persentase ketidakpuasan terhadap kinerja DPR berangsur meningkat dari waktu ke waktu.

Sehubungan dengan fungsi legislatif DPR, misalnya, lebih dari separuh responden menyatakan ketidakpuasan mereka terhadap kerja 
anggota dewan dalam membuat undang-undang. Demikian pula dalam mengontrol kerja pemerintah. Meskipun telah terjadi pergantian presiden dari Abdurrahman Wahid kepada Megawati Soekarno Putri, persentase ketidakpuasan responden dari waktu ke waktu kian besar. DPR dinilai semakin tidak berdaya mengawasi jalannya pemerintahan.

Sebenarnya rasa ketidakpuasan sebagian masyarakat terhadap kinerja DPR sudah dapat diprediksi sebelumnya. Meskipun DPR periode 1999-2004 mempunyai beberapa kelebihan dibandingkan dengan periode-periode sebelumnya, lembaga ini takpernah sepi dari berbagai persoalan internal. Isu korupsi, kolusi, dan nepotisme serta perpecahan internal partai-partai yang ada di dalamnya turut pula mewarnai kinerja para wakil rakyat. Puncaknya, Ketua DPR Akbar Tandjung terkait dengan kasus pidana pengucuran dana nonbujeter Bulog.

Takheran bila kinerja DPR selama ini masih belum memuaskan publik. Sepak terjang para wakil rakyat ini diyakini oleh mayoritas responden lebih menitikberatkan pada kepentingan partai masingmasing dan pribadi daripada kepentingan rakyat banyak.

\section{Konflik Eksekutif dan Legislatif} (Sumber: Litbang Kompas, 2002)

Kekuasaan cenderung korup, kekuasaan mutlak korup sejadijadinya. Komentar Lord Acton (1834-1902), sejarawan Inggris dalam sebuah surat, ini memberi peringatan terhadap kekuasaan yang mengatasnamakan negara. Makanya ia harus dikontrol supaya efektif dan efisien. Tentu hal itu demi kepentingan orang banyak. Salah satu alat kontrolnya adalah aturan main yang transparan.

Pemerintah atau eksekutif membuat rencana dan menjalankan pemerintahan. Parlemen atau legislatif mengawasi jalannya pemerintahan, baik dengan memantau langsung maupun dengan membuat rambu-rambu lewat produk perundang-undangan. Dalam praktiknya, kedua lembaga ini kerap tergoda untuk gagah-gagahan, saling mengecilkan peran satu sama lain, dan lebih dahsyat lagi, memicu konflik antarlembaga. Akibatnya, rakyat banyak yang seharusnya dilayani menjadi korban.

a. Konflik antara DPR dan Presiden Abdurrahman Wahid

1) Kasus pemberhentian Kapolri Jenderal Polisi Roesdihardjo dan melantik Jenderal Pol. Bimantoro sebagai pelaksana harian Kapolri. DPR menganggap presiden melangkahi DPR karena tidak pernah meminta persetujuan. 
2) Usaha pemberhentian gubernur BI Syahril Sabirin. Presiden mengusulkan Anwar Nasution sebagai penggantinya. DPR dalam rapatnya 6 Juni 2000 memutuskan bahwa Syahril Sabirin tetap dipercaya menjalankan tugasnya sebagai gubernur BI sampai pengadilan memutuskan kesalahannya secara yuridis.

3) Presiden mengusulkan pencabutan Ketetapan MPRS Nomor XXV/MPRS/1966 tentang Pembubaran PKI dan Dinyatakan Terlarang, serta larangan kegiatan untuk menyebarkan Komunisme, Marxisme, dan Leninisme. Beberapa anggota DPR dari partai Islam menolak keras usulan tersebut. Tanggal $29 \mathrm{Mei}$ 2000, semua fraksi MPR, termasuk FKB, menolak usulan pencabutan Tap MPRS tersebut.

4) Presiden mengusulkan calon Ketua MA, yakni Bagir Manan, dan Muladi (1 Januari 2001) mengundurkan diri. Presiden meminta DPR untuk mengajukan calon di luar keduanya. Komisi II DPR tetap pada pendiriannya menetapkan muladi dan Bagir Manan sebagai calon Ketua MA. Akhirnya presiden mengalah pada 5 Mei 2001 memilih Bagir Manan sebagai Ketua MA.

5) Tanggal 24 April 2000, presiden memberhentikan Jusuf Kalla dan Laksamana Sukardi dari jabatan menteri. Tanggal 29 Juni 2000 DPR menyetujui hak interpelasi berkaitan dengan pemecatan tersebut. Kepercayaan DPR kepada presiden semakin runtuh. Sebanyak 151 anggota DPR mengajukan usul penggunaan hak interpelasi menganggap presiden sungguhsungguh melanggar haluan negara yang telah ditetapkan oleh UUD dan ketetapan MPR.

\section{Perseteruan MA dan KY}

\section{(Tajuk Rencana, Kompas, 29 Juni 2006)}

Saling kritik dan adu argumen di antara dua lembaga negara merupakan hal yang wajar, apalagi dalam negara demokrasi. Namun, syaratnya harus ada perbaikan. Perseteruan antara Mahkamah Agung (MA) dan Komisi Yudisial (KY) di depan Mahkamah Konstitusi (MK) Selasa 27 Juni 2006, kedua lembaga itu saling melancarkan kritik dan argumentasi saat persidangan uji materi UU KY. Terasa sekali adanya perbedaan yang tajam di antara kedua lembaga tinggi negara itu. Bahkan, perbedaan itu mengarah pada rasa superioritas satu lembaga atas lembaga yang lainnya sehingga kedua lembaga itu bukan menjadi lembaga yang saling menopang, tetapi justru sebaliknya, saling mencurigai. 
Terus terang kita sangat menyayangkan hal itu sampai terjadi. Karena ketika kita bersepakat membangun KY, lembaga itu dimaksudkan untuk mengawasi kekuasaan kehakiman agar tidak menjadi lembaga yang tidak bisa disentuh (untouchable), lebih-lebih setelah kekuasaan itu berada dalam satu atap, yakni di bawah MA. KY diharapkan bisa menjadi lembaga independen yang mengusulkan pengangkatan hakim agung dan yang lebih penting lagi menjaga dan menegakkan kehormatan, keluhuran martabat, serta perilaku hakim. Sebagai sebuah lembaga baru, wajar apabila KY mengalami kegamangan dalam bekerja. Namun keadaan kemudian menjadi terasa lebih rumit ketika muncul resistensi dari MA yang keberatan untuk diawasi.

Di sinilah sebenarnya inti persoalan yang sedang kita hadapi. KY dianggap melampaui wewenang yang dimiliki, sebaliknya MA dianggap terlalu menutup diri. Ketika kedua lembaga tidak mau mengakui kelemahan dan sebaliknya justru menonjol kewenangannya, maka yang terjadi adalah perebutan kewenangan. Karena kita baru dalam tahapan awal dalam membangun demokrasi, kita berpendapat bahwa tidaklah mungkin demokrasi bisa dibangun apabila yang satu tak menunjang yang lain. Dalam membangun demokrasi tidak bisa ada lembaga yang merasa lebih penting dan harus menonjol, bahkan berkembang lebih maju dibandingkan dengan lainnya. Semua harus berkembang dengan tahapan yang sama agar sampai pada tujuan bersama, yakni bagaimana dengan sistem demokrasi ini kita bisa memperbaiki perikehidupan bangsa.

Bahkan sekarang ini tidak cukup lagi pilar demokrasi, yakni eksekutif, legislatif, dan yudikatif, yang tumbuh dan maju secara bersamaan, tetapi juga hsrus ditunjang oleh pilar-pilar lainnya, yakni pilar masyarakat madani (civil society) dan pelaku dunia usaha. Sebagai proses pembelajaran, saling kritik dan adu argumentasi tentu tidak ada salahnya. Yang terpenting bagaimana kedua lembaga itu kemudian mau saling menerima masukan dan bersama-sama memperbaiki sistem hukum di negara kita tercinta ini.

\section{MA-MK-KY, KEKABURAN KONSTITUSI}

(Mohammad Fajrul Falaakh, Kompas, 11 Juli 2006)

Tiga lembaga negara terlibat sengketa konstitusi. Sengketa dipicu pendapat sejumlah hakim agung bahwa ada wewenang Komisi Yudisial yang bertentangan dengan konstitusi. Sumber sengketa konstitusional antara MA-MK dengan KY adalah produk DPR dan Presiden, kekaburan hasil amandemen konstitusi oleh MPR, maupun 
hubungan antara kedua produk. Masalah ini dapat diselesaikan melalui jalan politik: kesepahaman MA-MK dan KY, revisi legislasi, atau amandemen konstitusi.

\section{Kepentingan MA dan $M K$}

Menurut UUD 1945, KY "memiliki wewenang lain dalam rangka menjaga dan menegakkan kehormatan, keluhuran martabat, dan perilaku hakim". UU KY merumuskan, kata hakim mencakup hakim agung dan hakim konstitusi (MK). UU KY tidak menambah atau mengurangi makna kata hakim karena sekadar memerincinya. Sebanyak 31 hakim MA mempersoalkan kaitan yuridis dan logis antara legislasi dan konstitusi. Penalaran mereka dikemas untuk menolak pengawasan KY: pengertian kata "hakim" adalah hakim pada umumnya dan hakim karier, calon hakim agung, tetpi tidak mencakup hakim agung. Karena itu tindakan KY mengawasi hakim agung, dan ketentuan UU KY 2004 yang terkait, harus dinyatakan bertentangan dengan konstitusi. Penalaran selanjutnya, pengertian "hakim" tidak mencakup hakim konstitusi.

Jika pendapat itu benar, tidak ada lembaga negara yang mengawasi hakim agung dan hakim konstitusi. Pendapat ini menuntut MA dan MK agar menggagas amandemen konstitusi tentang judicial impeachment process yang melibatkan KY dan lembaga perwakilan rakyat, seperti pemberhentian presiden dan wakil presiden di tengah masa jabatan. Sebenarnya pilihan MA dan MK jelas, mendiskriminasi akuntabilitas atau mengutamakan independensi dengan akuntabilitas. Melalui pengujian UU KY, MK menjadi medan sengketa sekaligus pihak yang berkepentingan. Pihak MA mencoba bersekutu dengan MK, terutama tiga hakim konstitusi yang berasal dari MA, untuk membebaskan diri dari pengawasan KY. MK menguji UU KY dalam pusaran kepentingan sendiri. KY pun dipanggil bersidang karena hukum acara MK memungkinkan, meski KY belum terbentuk saat UU KY diundangkan (Agustus 2004). Praktis MA-MK terlibat sengketa kewenangan antar lembaga negara dengan KY, yang dinilai bahwa pelaksanaan wewenangnya telah mengganggu independensi MA (Kompas, 28/6/2006).

Independensi kekuasaan kehakiman mengharuskan aspek "teknik yudisial" ada dalam kompetensi internal pengadilan, bahkan di tangan hakim pemutus perkara. Padahal wewenang KY mencakup disciplinary judicial procedure, misalnya menjaga dan menegakkan perilaku hakim. Pelaksanaan wewenang ini dapat mengarah penilaian tentang diskrepansi dalam penjatuhan pidana, misalnya putusan 
disertai atau tanpa kalimat "segera masuk penjara". Ini menurut KY untuk menilai judicial misconduct, seperti bersikap parsial dalam menangani perkara. Rekaman persidangan, jika ada, dan berita acara sidang dapat diperiksa untuk menengarai perilaku hakim. Memang, persinggungan tak mudah dihindari.

Menurut Pasal 24C Ayat (1) UUD 1945, MK menjadi tempat mengadili sengketa kewenangan konstitusional antar lembaga negara; bukan MPR. Namun, UU MK 2003 melarang MA menjadi pihak dalam sengketa jenis ini (Pasal 65). UU MK mereduksi kompetensi konstitusional MK karena untuk menjaga independensi MA dalam memutus perkara. KY berpeluang menepis rintangan ini guna menggugat MA agar memperlancar pelaksanaan wewenang konstitusional KY. Bukankah MA dan MK tak tergugah untuk membatalkan pertentangan Pasal 65 UU MK dengan konstitusi? Pihak MA berpendapat, konstitusi tak menginginkan pengawasan atas hakim agung (dan hakim MK) oleh KY.

\section{Hubungan konstitusi-legislasi}

Amandemen konstitusi menentukan satu wewenang eksplisit untuk KY. Selain berwenang mengusulkan calon hakim agung (wewenang eksplisit), Pasal 24B Ayat (1) UUD 1945 menentukan, KY "berwenang mengusulkan pengangkatan hakim agung" dan "mempunya wewenang lain dalam rangka menjaga dan menegakkan kehormatan, keluhuran martabat, serta perilaku hakim". Wewenang kedua bersifat implisit dan membutuhkan pendefinisian, atau bahkan kabur, namun tujuan pelaksanaan wewenang KY telah dirumuskan. Tujuannya "menjaga dan menegakkan kehormatan, keluhuran martabat, serta perilaku hakim", tetapi cara mencapinya tidak disebutkan. Ternyata UU KY membaliknya menjadi cara (Pasal 13 huruf b) bahwa KY "berwenang menegakkan kehormatan dan keluhuran martabat serta perilaku hakim". Kekaburan hubungan logisyuridis ini menuntut revisi legislasi dan atau amandemen konstitusi.

Konstitusi dan demokrasi tak menginginkan negara menjadi monster kekuasaan, besar atau kecil. Paradigma pemisahan kekuasaan, termasuk independensi kekuasaan kehakiman, tak lagi ditafsirkan secara atomistik. Ia dibangun bersama prinsip checks and balances, bukan pengaplingan bergaya hak milik. Ini soal pelik. Setelah lama terkungkung di bawah rezim otoriter, kekuasaan kehakiman di Indonesia mencoba memerdekakan diri dari pemerintah. Administrasi peradilan di bawah satu atap, masing-masing untuk MA dan MK, mungkin dinilai belum cukup. Tetapi melampaui batas-batas 
independensi, seperti akuntabilitas profesional dan institusional, akan menjerumuskan hakim ke tirani profesi. Pengadilan dan peradilan memang kompetansi hakim, tetapi keadilan adalah domain semua orang.

\section{Kembali ke UUD 1945 Antidemokrasi}

\section{(Adnan Buyung Nasution, Kompas, 10 Juli 2006)}

Sikap yang menuntut kembali ke UUD 1945 yang "asli" atau yang murni dan "konsekuen" yang biasa disebut "paham integralistik versi Soepomo", ibarat memutar jarum jam sejarah ke belakang, ke zaman Demokrasi Terpimpin (Orde Lama) atau Demokrasi Pancasila (Orde Baru) yang anti demokrasi. Banyak hasil penelitian ilmiah menunjukkan, UUD 1945 memiliki kelemahan atau cacat konseptual bagi pegangan berbangsa dan bernegara. Hasil penelitian Adnan Buyung Nasution yang dituangkan dalam disertasi di Universitas Utrecht, Belanda, juga dapat dilihat dari para ilmuwan FH UI, yaitu Dr. Benny K. Harman, Dr. Margarito Kamis, Dr. Aidul Fitri, dan yang dalam proses penulisan oleh sdr. Aulia Rahman, SH.

\section{Kelemahan konseptual}

Adanya pro dan kontra amandemen UUD 1945 dilihat dari perspektif konstitusionalisme adalah kerena belum jelasnya konsep kenegaraan (staatsidee) yang kita anut, apakah paham kenegaraan integralistik atau demokrasi konstitusional. Saya berbeda pendapat dengan kelompok yang menolak amandemen UUD 1945 yang menggunakan alasan: Pertama, telah menghilangkan MPR sebagai penjelmaan seluruh rakyat Indonesia. Kedua, mengubah sistem MPR menjadi bicameral, yang terdiri dari DPR dan DPD yang dipilih lewat pemilihan langsung sehingga dianggap mengarah pada federalisme dan menghilangkan eksistensi utusan golongan dan utusan daerah. Ketiga, hilangnya eksistensi MPR dianggap sebagai upaya mengubah sila keempat Pancasila: "Kerakyatan yang dipimpin oleh hikmah kebijaksanaanh dalam permusyawaratan/perwakilan".

Kelemahan mendasar paham integralistik versi Prof. Soepomo justru pada eksistensi institusi MPR ini yang dikatakan merupakan penjelmaan seluruh rakyat Indonesia dan karena itu memegang dan menjalankan sepenuhnya kedaulatan rakyat, sehingga memiliki kekuasaan tertinggi. Ketika MPR terbentuk, rakyat taklagi memiliki kedaulatan sebab telah habis diserahkan kepada MPR dalam bentuk pemberian suara pada pemilu. Dengan dipilihnya presiden oleh MPR, kedaulatan rakyat habis dipegang dan dijalankan oleh presiden. 
Konsekuensinya presiden memiliki kewenangan yang luas dan takterbatas.

Selain kelemahan konseptual itu, UUD 1945 juga memiliki kelemahan mendasar lain, yaitu dalam konstruksi hukumnya tidak mengindahkan pembatasan kekuasaan dengan pembagian ketiga cabang kekuasaan berdasarkan teori Montesquieu (eksekutif, legislatif, dan yudikatif) dan juga tidak cukup memberikan jaminan perlindungan hak asasi manusia. Kondisi ini melahirkan kekuasaan absolut di tangan presiden, tanpa ada checks and balances dari cabang kekuasaan lainnya, sehingga menimbulkan banyak peluang bagi terjadinya abuse of power dan penindasan hak asasi manusia.

\section{Sejarah ketatanegaraan}

Sebenarnya, saat founding fathers menerima diberlakukannya UUD 1945 yang dicetuskan Prof. Soepomo pada sidang PPKI 18 Agustus 1945 telah menyadari, UUD 1945 hanya bersifat sementara atau istilah Bung Karno "undang-undang dasar kilat". Mereka semua committed jika kelak keadaan mengizinkan, bangsa Indonesia akan melaksanakan pemilu untuk membuat UUD baru yang definit berasas kedaulatan rakyat.

Sejarah ketatanegaraan kita yang menggunakan konstitusi UUD 1945 sebagai landasan structural telah menghasilkan berbagai sistem pemerintahan yang berbeda-beda, bahkan pernah bertolak belakang secara konseptual. Dalam periode revolusi, hanya di masa kabinet Soekarno-Hatta yang pertama (Agustus 1945-sampai keluar maklumat X tanggal 16 Oktober 1945), berarti hanya dua bulan kita menerapkan UUD 1945 yang "asli" yang kekuasaan sepenuhnya di tangan presiden. Maklumat Wakil Presiden No. X mengubah secara mendasar sistem ketatanegaraan dari Presidesial ke Parlementer, meski tetap menggunakan UUD 1945 sebagai konstitusi.

Pada 1949 bangsa Indonesia telah mengganti UUD 1945 dengan Konstitusi RIS dan tahun 1950 lagi-lagi diganti dengan UUD Sementara 1950, tetapi tetap menganut paham demokrasi konstitusional meski dengan sistem berlainan. Baru tahun 1955 pertama kali diselenggarakan pemilu dan dibentuk Majelis Konstituante untuk membuat UUD baru yang definitif. Sebelum tugasnya selesai, Konstituante dibubarkan melalui Dekrit Presiden Soekarno 5 Juli 1959. Bukan disebabkan Konstituante tak berhasil atau mengalami deadlock dalam menyusun UUD baru sebagaimana diajarkan dalam semua buku pelajaran sejarah versi pemerintah, tetapi 
karena ada kepentingan politik dari kalangan militer dan pendukung Soekarno.

Dengan diberlakukannya kembali UUD 1945 melalui Dekrit 5 Juli 1959, timbul kembali pemerintahan otoriter di bawah panji Demokrasi Terpimpin Soekarno dilanjutkan rezim otoriter Orde Baru Soeharto dengan panji Demokrasi Pancasila. Dalam masa pemerintahan transisi baik di zaman Habibie, Abdurrahman Wahid, dan Megawati sebelum Pemilu 2004, kita menyaksikan betapa lemahnya UUD 1945 mengatur penyelenggaraan kekuasaan negara karena sifatnya yang multi-interpretasi. Pemegang kekuasaan negara bisa melakukan berbagai distorsi dan devisiasi nilai-nilai demokrasi dan sistem pemerintahan.

Kita pantas khawatir, jangan-jangan dewasa ini kita menghadapi pengulangan sejarah, adanya sisa-sisa kalangan militer dan pendukung Soekarno yang menghendaki kembalinya "Demokrasi Terpimpin". Dulu mereka berhasil menjegal Majelis Konstituante dengan memakai "pedang" Dekrit 5 Juli 1959. Atau pendukung Soeharto yang menghendaki kembalinya "Demokrasi Pancasila" yang dengan landasan UUD 1945 yang "murni dan konsekuen" berhasil berkuasa selama 32 tahun. Tuntutan untuk kembali ke UUD 1945 jelas diwarnai nostalgia atau sindrom pada kekuasaan otoriter dan totaliter yang pernah dinikmati di masa lampau dan merasa "kehilangan" atau tak bisa eksis lagi untuk membangun kekuatan politik dalam konteks UUD 1945 hasil amandemen.

\section{Mengandung kelemahan}

UUD 1945 hasil amandemen telah memberikan tatanan kenegaraan yang lebih baik meski ada beberapa kelemahan. Kemajuan yang telah dicapai telah memberikan perlindungan terhadap hak asasi manusia, memberikan batasan terhadap kekuasaan negara, pemilihan presiden langsung oleh rakyat, pembentukan Mahkamah Agung yang mandiri terlepas dari Departemen Kehakiman, pembentukan Mahkamah konstitusi, Komisi yudisial, dan lain-lain.

Beberapa kelemahan yang perlu diperbaiki, yaitu: Pertama, terkait dengan masalah konseptual. MPR tidak memiliki konsep atau desain ketatanegaraan yang jelas tentang arah dan tujuan yang hendak dicapai melalui serangkaian amandemen itu. Kedua, menyangkut masalah teknik, yuridis, yakni lemahnya kemampuan legal drafting dalam merumuskan dan menyusun pasal-pasal, yang tampak dari segi sistematika yang rancu maupun bahasa hukum yang dipergunakan. Akibatnya, banyak pasal hasil amandemen yang tumpang tindih, 
kontradiktif, dan memungkinkan multitafsir. Namun, adanya kelemahan tersebut tidak berarti kita harus kembali kepada UUD 1945. Komisi konstitusi perlu dibentuk kembali guna merancang draf komprehensif amandemen UUD baru dengan struktur dan sistematika yang lebih baik, yang tegas dan jelas mengacu kepada konsep negara.

Demokrasi Konstitusional, seperti diintroduksi Hatta dan Yamin, yaitu yang meletakkan rakyat sebagai pemegang kedaulatan, menegakkan supremasi hukum, pembagian kekuasaan yang jelas antara eksekutif, legislatif, dan yudikatif (trias politika), pertanggungjawaban pemerintahan pada rakyat (public accountability), dan dihormatinya hak asasi manusia. Konsep ini merujuk pada cirri-ciri yang bisa ditetapkan secara eksplisit atau bisa dianggap bagian inti dari nilai konstitusional sebagai cita-cita yang selalu merupakan variable achievement. Demokratisasi di Indonesia harus berlangsung pada dua dataran sekaligus, yaitu dataran konseptual dan dataran praksis agar tidak tambal sulam.

\section{UU Kewarganegaraan (Ketika Paradigma Berubah)}

(Hamid Awaludin, Kompas, 25 Juli 2006)

Sebuah kepastian telah muncul. Garis demarkasi antara "kami" dan "mereka" telah dikubur. Kini hanya ada sebuah perahu kebersamaan, bernama Indonesia. Itulah UU Kewarganegaraan yang baru, menggantikan UU Kewarganegaraan Nomor 62 Tahun 1958. Para wakil rakyat bersama pemerintah sepakat, diskriminasi etnis dan jender yang diteguhkan UU lama harus menjadi masa silam bangsa.

\section{Paradigma baru}

UU Kewarganegaraan yang baru tidak sekadar mengatur siapa dan bagaimana cara menjadi warga negara dan kehilangan status kewarganegaraan. Sebagai karya monumental yang mengubah paradigma dan perilaku. Konsep bangsa Indonesia asli dijelaskan sebagai orang Indonesia yang menjadi warga negara Indonesia sejak kelahirannya dan tidak pernah menerima kewarganegaraan lain atas kehendak sendiri. Konsep itu diilhami paradigma, bahwa status kewarganegaraan seseorang ditentukan status yuridis, bukan etnis dan ras. Dengan demikian, perdebatan yang diskriminatif dan konfliktif tentang asli dan tidak asli sudak ditutup. Tak ada lagi pemojokan atas etnis tertentu di negeri ini. Semua etnis dan komunitas, secara yuridis, memiliki tanah yang sama.

Dengan UU ini, takada lagi anak-anak yang harus terusir dari tumpah darahnya hanya karena status yuridis. UU ini menegaskan, 
anak yang lahir dari ibu orang Indonesia dan ayah orang asing tidak otomatis mengikuti warga negara ayahnya. Bahkan pada saat bersamaan, anak boleh menjadi warga negara Indonesia dan warga negara ayahnya hingga usia 18 tahun. Setelah itu, sang anak boleh menentukan kewarganegaraan yang dipilih. Anak-anak Indonesia hasil perkawinan ayah dan ibu warga negara Indonesia tetapi lahir di negara-negara yang menganut prinsip ius soli (menjadi warga negara karena kelahiran) seperti AS, juga diakomodasi UU ini. Anak-anak Indonesia bisa menjadi warga negara di mana ia lahir sekaligus warga negara Indonesia pada saat bersamaan hingga mereka mencapai usia 18 tahun untuk menentukan pilihan. Dalam perspektif ini, kita menganut prinsip kewarganegaraan ganda terbatas.

\section{Nasib anak-anak}

Dari sini terlihat, para wakil rakyat dan pemerintah berpihak pada anak-anak bangsa yang lahir hasil dari perkawinan campuran atau lahir di negara-negara yang menganut prinsip kewarganegaraan ditentukan oleh tempat kelahiran, seperti AS. Pembuat UU memahami betapa getirnya kehidupan anak-anak yang diombang-ambingkan status kewarganegaraan. Kasus-kasus memilukan sering menyentak kemanusiaan kita. Banyak anak harus berpisah dengan ibunya dan terusir dari Indonesia karena kesewenangan hukum kita. Berapa banyak anak hasil kawin campur (berayah orang asing) terkena implikasi negatif saat orang tuanya bercerai, mengharuskan anak-anak ikut ayahnya ke negeri asal.

Hal lain, perempuan Indonesia yang menikah dengan pria asing tidak otomatis ikut kewarganegaraan suami seperti UU sebelumnya. Ia bisa tetap menjadi warga negara Indonesia. Bahkan ia bisa menjadi sponsor suaminya untuk memiliki status permanent residence atau menjadi warga negara Indonesia. Bagi saudara-saudara kita yang karena alasan tertentu menjadi warga negara asing dan ingin kembali menjadi warga negara Indonesia, pintu terbuka lebar. Apalagi jika mereka menanggalkan kewarganegaraan Indonesianya karena terpaksa.

\section{Spektakuler}

Ada terobosan spektakuler. Orang asing yang berjasa dan mengharumkan nama bangsa dan negara dapat menjadi warga negara Indonesia tanpa proses naturalisasi. Kategori jasa bisa berupa hasil pikiran, karya seni, atau perannya pada olahraga. Dengan ini kita tak akan pernah lagi mendengar keluhan seorang Hendrawan yang bejasa 
mengangkat nama bangsa lewat Thomas Cup atau menjadi juara dunia bulu tangkis, tetapi merana jika berhadapan dengan aturan yang tertutup dan tidak fair. Kita perlu menyadari sebagai bangsa besar dan terbuka. Konsekuensinya, kita harus terbuka memberi penghargaan bagi siapa saja yang berjasa dan berbuat baik bagi bangsa dan negara. Sebagai bangsa kita tidak ingin terbelah garis etnis dan ras. Kita tak ingin tercabik karena nihilnya penghargaan jender. Mimpi buruk tentang ini semua sudah berlalu.

\section{Penutup}

Materi untuk pembelajaran Pendidikan Kewarganegaraan erat sekali hubungannya dengan kajian dalam bidang politik. Sedangkan kajian dalam bidang ilmu politik sangat dipengaruhi oleh perkembangan realitas politik di suatu negara baik yang masuk dalam wilayah supra struktur politik maupun yang masuk infra struktur politik. Pembelajaran dan kajian PKN yang mengabaikan perkembangan dan dinamika politik akan kehilangan kontektulitas, kehilangan daya tarik, serta kurang bermanfaat bagi peserta didik. Oleh karena itu, pemahaman dan penguasaan pengampu Pendidikan Kewarganegaraan pada berbagai persoalan politik beserta dinamika dan perkembangannya adalah merupakan keniscayaan.

\section{Daftar Pustaka}

Branson, Margaret S., dkk. (1999). Belajar Civic Education dari Amerika. Yogyakarta: Kerjasama LKIS dan Asia Foundation.

Center for Civic Education. (1994). National Standars for Civic and Government. Calabasas USA..

Cholisin. (2004). "Konsolidasi Demokrasi Melalui Pengembangan Karakter Kewarganegaraan”. Jurnal Civics Vol. 1, No.1, 2004. PPKN FIS UNY.

Hamdan Mansoer. (2003). Strategi Pembinaan MPK di Perguruan Tinggi. Dirjen. Dikti, Depdiknas, Bagian Proyek Pendidikan Tenaga Akademik 2003.

Muchson. (2003). "Pendidikan Kewaranegaraan Paradigma Baru". Makalah. Seminar, 29 Maret 2003, UNS Surakarta. 
Nurul Fatchiati. (2002). DPR di Mata Publik, (di Buku Indonesia dalam Krisis), Penerbit Kompas, Jakarta.

Print, Murray et al. (1999). Civic Education for Civil Society. London: Asian Academic Press.

Pusat Kurikulum Balitbang Depdiknas. (2002). Kurikulum Berbasis Kompetensi Pendidikan Kewarganegaraan. Puskur. Balitbang. Depdiknas. Jakarta.

Sisilia Srisuwastuti. (2002). DPR dan Fungsi Legislasi (di Indonesia dalam Krisis). Penerbit Kompas, Jakarta.

Wahab, Abdul Azis. (2000). "New Paradigm and Curriculum Design forNew Indonesian Civic Education". Paper, The International Seminar. March 29, 2000, at Bandung.

Waterworth, Peter. (1998). "Trends in Social Studies Education and Citizenship Education." Paper. Faculty of Education, Deakin University, Australia.

Harian Kompas, 29 Juni 2006

Harian Kompas, 10 Juli 2006

Harian Kompas, 11 Juli 2006

Harian Kompas, 25 Juli 2006

\section{Biodata Penulis}

Sunarso, M.Si., lahir di Karanganyar, 21 Mei 1960. Tamat S1 Fakultas Ilmu Sosial dan Ilmu Politik UGM tahun 1985 dan S2 Program Studi Ketahanan Nasional Pasca Sarjana UGM tahun 1995. Sejak tahun 1987 menjadi staf pengajar di FPIPS (sekarang FISE) Universitas Negeri Yogyakarta Jurusan MKU dan pada tahun 1999 dipindahtugaskan di Jurusan PPKN pada fakultas dan universitas yang sama. Mata kuliah yang diampu sejak tahun 1987 hingga sekarang adalah Pendidikan Pancasila, Pendidikan Kewarganegaraan, serta Perbandingan Sistem Pemerintahan. 